\title{
HUBUNGAN ANTARA KEPEMIMPINAN EFEKTIVITAS GURU DALAM PEMBELAJARAN DENGAN KREATIVITAS SISWA (STUDI PADA SISWA KELAS XI DI MADRASAH ALIYAH ASSALAM BALEENDAH)
}

\author{
RELATIONSHIP BETWEEN THE LEADERSHIP OF TEACHER EFFECTIVENESS \\ IN LEARNING WITH STUDENT CREATIVITY (STUDY IN CLASS XI AT MADRASAH \\ ALIYAH ASSALAM BALEENDAH)
}

\author{
Ida Siti Rodiah
}

Guru Madrasah Aliyah Assalam Baleendah Bandung

E-mail: edasiti@studen.upi.edu

\begin{abstract}
ABSTRAK
Kreativitas akan menghasilkan berbagai inovasi dan perkembangan baru dalam suatu kehiduapan. Siswa dituntut untuk berpikir kreativ dalam proses pembelajaran di kelas. Kepemimpinan guru yang baik dapat mendorong siswa mengembangkan kreativitas. Tujuan penelitian untuk memperoleh profil yang jelas mengenai hubungan kepemimpinan efektivitas guru dalam pembelajaran dengankreativitas siswa Kelas XI di MA Assalam Baleendah. Metode yang digunakan dalam penelitian ini adalah deskriptif dan verifikatif dengan pendekatan kuantitatif. Penelitian ini melibatkan guru dan siswa Kelas XI di MA Assalam Baleendah sebagai narasumber.Hasil penelitian bahwa kepemimpinan efektivitas guru dalam pembelajaran cukup baik, kreativitas siswa cukup baik, dan terdapat hubungan kepemimpinan efektivitas guru dalam pembelajaran dengankreativitas siswa Kelas XI di MA Assalam Baleendah.
\end{abstract}

Kata kunci : kepemimpinan, kepemimpinan guru, kreativitas siswa

\section{ABSTRACT}

Creativity will produce new innovations and developments in a lifetime. Students are required to think creatively in the process of learning in the classroom. Good teacher leadership can encourage students to develop creativity. The purpose of the research is to obtain a clear profile about the relationship of teacher effectiveness leadership in learning with creativity of students of Class XI in MA Assalam Baleendah.The method used in this research is descriptive and verifikatif with quantitative approach. This research involves teachers and students of Class XI in MA Assalam Baleendah as resource persons. The result of the research that the leadership of teachers effectiveness in learning is good enough, the students' creativity is good enough, and there is relationship of teacher effectiveness leadership in learning with creativity of the students of Class XI in MA Assalam Baleendah.

Keywords: leadership, teacher leadership, student creativity

\section{PENDAHULUAN}

Belajar dan pembelajaran merupakan kegiatan yang tidak terpisahkan dalam kehidup manusia. Dengan belajar, manusia dapat mengembangkan potensi-potensi yang dimilikinya. Tanpa belajar, manusia tidak mungkin dapat memenuhi kebutuhankebutuhannya. Semua aktivitas keseharian membutuhkan ilmu yang hanya didapat dengan belajar. Pada dasarnya pendidikan merupakan proses untuk membantu manusia dalam mengembangkan potensi dirinya sehingga mampu menghadapi setiap perubahan yang terjadi. Sejalan dengan perkembangan masyarakat dewasa ini, pendidikan banyak menghadapi berbagai tantangan dan hambatan. Salah satu hambatannya adalah rendahnya mutu pendidikan di negara ini, sehingga dengan adanya hambatan tersebut akan menjadikan sebuah tantangan bagi pengelola pendidikan untuk meningkatkan mutu pendidikan di Indonesia.

Pembelajaran pada dasarnya merupakan upaya untuk mengarahkan anak didik dalam proses belajar sehingga meraka dapat memeperoleh tujuan belajar sesuai dengan apa yang diharapkan. Pembelajaran hendaknya memperhatikan kondisi individu anak karena mereka yang akan belajar. Anak didik merupakan individu yang berbeda satu sama lain. Oleh karena itu pembelajaran hendaknya memperhatikan perbedaanperbedaan individual anak tersebut, sehingga 
pembelajaran benar-benar dapat meroboh kondisi anak dari yang tidak tahu menjadi tahu, dari yang tidak paham menjadi paham serta dari yang berperilaku kurang baik menjadi baik. Kondisi riil anak seperti ini, selama ini kurangmendapat perhatian di kalangan pendidik. Hal ini terlibat dari perhatian sebagaiguru atau pendidik yang cenderung memperhatikan kelas secara keseluruhan,tidak perorangan atau kelompok anak, sehingga perbedaan individual kurang mendapat perhatian.

Proses pembelajaran di sekolah merupakan suatu kegiatan yang perlu direncanakan dengan matang. Perencanaan tersebut meliputi kegiatan belajar mengajar, pengelolaan kelas maupun hasil belajar di kelas. Oleh karena itu, perencanaan pembelajaran yang kita kenal dengan Rencana Pelaksanaan Pembelajaran (RPP) menjadi suatu hal yang sangat penting. Penyusunan rencana pelaksanaan pembelajaran berguna untuk membantu dan memudahkan guru agar program pembelajaran yang dilaksanakan benar-benar terfokus pada kegiatan peserta didik, sehingga perlu disusun suatu perangkat rencana pelaksanaan pembelajaran, pengelolaan kelas, dan penilaian hasil belajar.

Fungsi pembelajaran sebagai proses yaitu pembelajaran sebagai sistem terdiri dari sejumlah komponen yang terorganisir antara lain tujuan pembelajaran, materi pembelajaran, strategi dan metode pembelajaran, media pembelajaran/alat peraga, pengorganisasian kelas, evaluasi pembelajaran, dan tindak lanjut pembelajaran (remedial dan pengayaan). Berdasarkan fungsi pembelajarn tersebut, pembelajaran perlu dilakukan secara kreatif.

Kreativitas merupakan suatu tuntutan pendidikan dan kehidupan yang sangat penting. Kreativitas akan menghasilkan berbagai inovasi dan perkembangan baru dalam suatu kehidupan. Individu yang kreatif akan selalu dibutuhkan oleh lingkungannya karena mereka dapat mampu memenuhi kebutuhan lingkungan yang terus berubah dan mampu untuk bertahan dalam kompetisi global yang dinamis dan ketat.

Berdasarkan hasil survei yang dilakukan Indonesian Education Sector Survey Report, dijelaskan bahwa pendidikan di Indonesia menekankan pada keterampilan-keterampilan rutin dan hafalan semata-mata. Pendidikan di Indonesia masih kurang untuk memberikan peluang bagi pengembangan kreativitas. Ranah di sekolah yang terutama dilatih adalah ranah kognitif yang meliputi pengetahuan, ingatan dan kemampuan berpikir logis atau penalaran. Sementara perkembangan ranah afektif (sikap dan perasaan) dan ranah psikomotorik (keterampilan) kurang dikembangkan (Suyahni, 2014:20). Pentingnya kreativitas tertera dalam Sistem Pendidikan Nasional No 20 Tahun 2003 yang intinya antara lain adalah melalui pendidikan diharapkan dapat mengembangkan potensi peserta didik agar menjadi manusia yang bertakwa, berakhlak mulia, cakap, kreatif, juga mandiri (Juliantine, 2009).

Pengamatan selama pembelajaran pada siswa Kelas XI Madrasah Aliyah Assalam Baleendah dari tahun 2010 hingga 2017 ditemukan bahwa pada saat diskusi kelompok sebagian siswa terlihat mengobrol dengan teman sebangku dan tidak memperhatian kelompok penyaji. Saat diberi waktu bertanya siswa banyak diam dan tidak mau mengajukan pertanyaan, sehingga diskusi terlihat kurang berjalan lancar. Siswa terlihat pasif dan penyaji mengalami kesulitan dalam menjawab, hal ini terlihat saat teman yang bertanya merasa kurang puas dengan jawaban dari penyaji, penyaji sering menjawab pertanyaan dengan jawaban yang sama dengan berulang-ulang. Dari hasil observasi tersebut dapat dikatakan bahwa siswa kurang memiliki rasa ingin tahu akan sesuatu yang baru dan siswa kurang mampu mencetuskan gagasan atau ide-ide yang baru dalam menjawab pertanyaan dari temantemannya.

Menurut Ismail (2003: 133) kreativitas dapat menjadi kekuatan (power) yang 
menggerakkan manusia dari yang tidak tahu menjadi tahu, tidak bisa menjadi bisa, bodoh menjadi cerdas, pasif menjadi aktif, dan sebagainya. Sementara itu siswa yang memiliki kreativitas yang tinggi disertai rasa ingin tahu yang besar dan haus akan tantangan berpikir membuat siswa gemar melakukan eksplorasi (Kisti dan Fardana, 2012).

Kepemimpinan guru yang baik dapat mendorong siswa mengembangkan kreativitas. Kepemimpinan adalah suatu kegiatan untuk mempengaruhi, mengarahkan, dan menggerakkan orang lain baik individu maupun kelompok untuk mencapai suatu tujuan. Kepemimpinan dapat dilakukan oleh siapa saja, dimana saja, dan kapan saja dan tidak harus diikat dalam suatu organisasi tertentu. Siapa saja dapat melakukan kepemimpinan asalkan mempunyai keterampilan dan kemampuan dalam hal mempengaruhi orang lain untuk mencapai tujuan tertentu. Penerapan kepemimpinan sangat ditentukan oleh situasi kerja atau keadaan anggota dan sumberdaya pendukung organisasi. Menurut Siagian (2012:77), kepemimpinan merupakan kemampuan seseorang yang menduduki jabatan sebagai pemimpin untuk memimpin yang terdiri dari mengarahkan, membimbing dan mempengaruhi sesuatu prilaku orang yang dipimpin untuk berfikir dan bertindak sedemikian rupa melalui prilaku yang positif guna mencapai tujuan. Seorang pemimpin sebaiknya mempunyai kemampuan dalam memimpin yang dapat menunjang tercapainya tujuan yang diharapkan.

Guru merupakan komponen terpenting dalam kesuksesan pembelajaran. Daresh dan Playco (1995) mendefinikan kepemimpinan pembelajaran sebagai upaya memimpin para guru agar mengajar lebih baik, yang pada gilirannya dapat memperbaiki prestasi belajar siswanya. Kepemimpinan pembelajaran adalah kepemimpinan yang memfokuskan/ menekankan pada pembelajaran yang komponen-komponennya meliputi kurikulum, proses belajar mengajar, asesmen (penilaian hasil belajar), penilaian serta pengembangan guru, layanan yang optimal dalam pembelajaran, dan pembangunan komunitas belajar di sekolah.

Pentingnya berpikir kreatif bagi siswa yaitu lebih melibatkan siswa sebagai pemikir, menigkatkan perilaku kreatif, menggerakan potensi kreativitas siswa dalam mengumpulkan suatu ide dan siswa terlibat secara aktif dalam proses pembelajaran. Tugas utama guru dalam mengelola pembelajaran untuk mengasah keterampilan siswa berpikir kreatif mencakup merancang perencanaan pembelajaran melalui perumusan Rencana Pelaksanaan Pembelajaran (RPP), menerapkan rencana pembelajaran dalam kegiatan belajar siswa, menilai proses dan hasil belajar siswa, dan mengevaluasi pembelajaran.

Upaya untuk mewujudkan keterampilan berpikir kreatif terkait dengan proses pembelajaran yang kurang variatif dan kreatif adalah memberikan pembelajaran dengan menggunakan model pembelajaran yang tepat sesuai dengan materi. Guru harus dapat meningkatkan keterampilan dalam mengelola kelas. Pengelolaan kelas menggambarkan tetang proses untuk memastikan bahwa pembelajaran dalam kelas dapat berjalan lancar tanpa terganggu dengan perilaku prilaku siswa yang mengganggu. Guru harus mempunyai cara yaitu dengan penggunaan model pembelajaran yang dapat berguna untuk meningkatkan keterampilan berpikir kreatif siswa.

Beberapa penelitian terdahulu yang telah dilakukan antara lain oleh Tikky Suwantikno Sutjiaputra (2002) tentang Pengaruh gaya kepemimpinan dan kreativitas guru di dalam kelas sesuai persepsi siswa terhadap kreativitas siswa Sekolah Dasar. Hasil analisis dengan menggunakan Pearson Product Moment diperoleh informasi bahwa korelasi antara setiap dimensi gaya kepemimpinan (telling, Participating, Delegating) dengan kreativitas siswa tidak ada yang sesuai dengan pemahaman teoritis Jurnal Penelitian Pendidikan 
bahwa gaya kepemimpinan telling dan delegating berhubungan secara signifikan dan negative, sedangkan gaya kepemimpinan selling dan participating berhubungan secara signifikan dan positif. Namun dari hasil analisis tersebut ditemukan korelasi yang signifikan antara setiap gaya kepemimpinan (telling, selling, participating, delegating) dengan kreativitas guru di dalam kelas yang sesuai dengan kajian teoritis, dimana gaya kepemimpinan telling berkorelasi negative dan signifikan dengan kreativitas guru, sedangkan gaya kepemimpinan selling dan participating berkorelasi positif dan signifikan dengan kreativitas guru, korelasi gaya kepemimpinan selling dengan kreativitas guru dan korelasi antara gaya kepemimpinan participating dengan kreativitas guru.

Penelitian Putri, Femmy Eka Kartika (1998) tentang Faktor-faktor yang berpengaruh terhadap kreativitas siswa SMU Negeri 70 di Jakarta : (menggunakan pendekatan pribadi, proses, pendorong, dan produk kreatif dengan analisis model persamaan struktural). Hasil penelitian menunjukkan bahwa faktor pribadi kreatif, yaitu sikap kreatif siswa dan faktor pendorong kreatif, yaitu macam-macam kegiatan kreatif siswa di sekolah, mempunyai pengaruh yang signifikan terhadap produk kreatif siswa.

Penelitian Yunia Mandasari dan Nadjamuddin (2015) tentang Pengaruh Gaya Belajar Siswa Terhadap Kreativitas Siswa pada Mata Pelajaran Seni Budaya dan Keterampilan (SBK) Materi Seni Rupa Menggambar Kelas 4 di Madrasah Ibtidaiyah Darul Ulum Karang Binangun Belitang Oku Timur. Hasil penelitian menunjukkan bahwa dari uji data dengan menggunakan Korelasi Product Moment ini bahwa "ada hubungan antara gaya belajar siswa terhadap kreativitas siswa mata pelajaran SBK materi seni rupa mengambar" karena keriteria apabila $r_{x y}<r$ tabel maka Ho diterima jika $>\mathrm{r}$ tabel maka Ho ditolak. Dapat dinilai bahwa df 15 pada taraf $5 \%=0,514$ dan $1 \%=0,641$, jika kita menggunakan salah satu dari $\mathrm{r}$ tabel maka dapat dinilai $(3,919)>\mathrm{r}$ tabel $(0,641)$, berarti Ho ditolak.

Faiqotul Hikmah (2015). Upaya Guru PAI dalam Mengembangkan Kreativitas Siswa pada Mata Pelajaran Pendidikan Agama Islam Kelas VIII SMP Nusantara Plus Ciputat. Berdasarkan hasil penelitian dapat diketahui bahwa guru membuat rencana pembelajaran berupa silabus, RPP dan menggunakan metode, strategi serta media yang relevan guna mengembangkan kreativitas siswa pada mata pelajaran PAI. Kreativitas siswa dapat berkembang dalam pembelajaran PAI dengan cara menggunakan metode, strategi serta media yang relevan dengan materi yang diajarkan.

Berdasarkan pemaparan latar belakang penelitian diatas, maka rumusan masalah penelitian ini adalah: (1) Bagaimana kepemimpinan efektivitas guru dalam pembelajaran di Kelas XI MA Assalam Baleendah; (2) Bagaimana kreativitas siswa Kelas XI di MA Assalam Baleendah; dan (3) Bagaimana hubungan kepemimpinan efektivitas guru dalam pembelajaran dengan kreativitas siswa Kelas XI di MA Assalam Baleendah

Secara umum tujuan penelitian ini adalah untuk memperoleh profil yang jelas mengenai hubungan kepemimpinan efektivitas guru dalam pembelajaran dengan kreativitas siswa Kelas XI di MA Assalam Baleendah. Secara khusus tujuan penelitian ini untuk mengetahui: (1) Kepemimpinan efektivitas guru dalam pembelajaran di Kelas XI MA Assalam Baleendah; (2) Kreativitas siswa Kelas XI di MA Assalam Baleendah; dan (3) Hubungan kepemimpinan efektivitas guru dalam pembelajaran dengan kreativitas siswa Kelas XI di MA Assalam Baleendah

\section{METODE}

Penelitian ini menggunakan penelitian deskriptif dengan pendekatan kuantitatif. Metode deskriptif berusaha mendeskripsikan berbagai informasi dengan melakukan kajian analitis kritis terhadap informasi atau data 
yang diperoleh tersebut. Nasution (2003, hlm. 24) mengemukakan penelitian deksriptif merupakan penelitian yang bertujuan untuk mengadakan deskripsi untuk memberikan gambaran yang jelas tentang situasi-situasi sosial. Sedangkan Nazir (2012, hlm. 34) mengatakan bahwa penelitian deskriptif merupakan suatu metode dalam meneliti status sekelompok manusia, suatu objek, suatu set kondisi, suatu sistem pemikiran, ataupun suatu kelas peristiwa pada masa sekarang. Tujuan penelitian ini adalah untuk membuat gambaran atau lukisan secara sistematis, faktual dan akurat mengenai fakta-fakta, sifat-sifat serta hubungan antar fenomena yang diselidiki.

Sesuai dengan permasalahan yang diteliti, maka peneliti menggunakan metode peneltian yaitu pendekatan kuantitatif dengan alasan metode ini dianggap tepat, karena hal sesuai dengan pernyataan Sugiyono (2014:14) "Bahwa penelitian kuantitatif dapat diartikan sebagai metode penelitian yang berlandaskan pada filsafat positvisme, digunakan untuk meneliti pada populasi atau sampel tertentu, random, pengumpulan data mengggunakan instrumen penelitian, analisis data bersifat kuantitatif atau statistik dengan tujuan untuk menguji hipotesis yang telah ditetapkan". Dalam pengolahan data, peneliti menggunakan teknik analisis data statistik deskriptif. Teknik ini digunakan peneliti karena pengumpulan data dilakukan dengan cara penyebaran kuesioner dan cara pengolahannya dengan perhitungan presentase.

Berdasarkan pendapat diatas, peneliti menganalisis secara cermat efektivitas kepemimpinan guru dan kreativitas siswa Kelas XI di Madrasah Aliyah Assalam Baleendah.

Penelitian ini melibatkan guru dan siswa Kelas XI di MA Assalam Baleendah sebagai narasumber mengenai gambaran kepemimpinan efektivitas guru dan kreativitas siswa yang berjumlah 10 orang guru dan 35 siswa Kelas XI.
Populasi adalah keseluruhan subjek penelitian(Arikunto, 2010:173). Populasi yang digunakan dalam penilitian ini adalah siswa kelas XI Madrasah Aliyah Assalam Baleendah yang berjumlah 28 siswa. Sampel yang digunakan dalam penelitian ini didapat dengan teknik pengambilan sampel (teknik sampling) Nonprobability Samplingdengan Sampling Jenuh. Menurut Riduwan (2012:64), “sampling jenuh ialah teknik pengambilan sampel apabila semua populasi digunakan sebagai sampel dan dikenal juga dengan istilah sensus". Lebih lanjut Arikunto (2006:134), mengemukakan "apabila subyeknya kurang dari 100, lebih baik diambil semua sehingga penelitiannya merupakan penelitian populasi." Dalam penelitian ini, melihat jumlah populasi sebanyak 28 orang, oleh karena itu, semua anggota populasi dijadikan sampel penelitian. Oleh karena itu,sampel yang diambil untuk penelitian ini sebanyak 28 orang.

Analisis verifikatif bertujuan untuk mengetahui hubungan antar variabel melalui suatu pengujian hipotesis penelitian dengan menggunakan perhitungan statistik. Dalam penelitian ini, metode analisis verifikatif digunakan untuk menguji hubungan antara variabel independen yaitu kepemimpinan efektivitas guru dalam pembelajaran dengan variabel dependen yaitu kreativitas siswa.

\section{Uji Normalitas Data}

Menurut Ghozali (2009:110) 'Uji normalitas bertujuan untuk mengetahui apakah masingmasing variabel berdistribusi normal atau tidak. Uji normalitas diperlukan karena untuk melakukan pengujian-pengujian variabel lainnya dengan mengasumsikan bahwa nilai residual mengikuti distribusi normal. Jika asumsi ini dilanggar maka uji statistik menjadi tidak valid dan statistik parametrik tidak dapat digunakan."

Uji normalitas digunakan untuk mengetahui bahwa data yang diambil berasal dari populasi berdistribusi normal. Kaidah yang digunakan untuk menguji normalitas Jurnal Penelitian Pendidikan 
yaitu skor Sig, yang ada pada hasil penghitungan kolmogorov-smirnov. Apabila angka Sig. lebih besar atau sama dengan 0,05 maka data tersebut berdistribusi normal akan tetapi apabila kurang dari 0,05 maka data tersebut tidak berdistribusi normal.

\section{Analisis regresi linier sederhana}

Digunakan untuk mengetahui ada tidaknya hubungan antar variabel sekaligus untuk menaksir harga variabel Y berdasarkan harga variabel $X$, dan taksiran perubahan variabel Y untuk setiap satuan perubahan variabel $\mathrm{X}$. Hubungan tersebut umumnya dinyatakan dalam bentuk persamaan matematik yang mempunyai hubungan fungsional antara variabel-variabel tersebut. Penulis dalam penelitian ini menggunakan analisis regresi linier sederhana dengan persamaan:

$$
\mathrm{Y}=\mathrm{a}+\mathrm{bX}
$$

$$
\begin{array}{ll}
\text { Keterangan : } & \mathrm{Y}=\text { Kreativitas siswa } \\
& \mathrm{X}=\text { Kepemimpinan }
\end{array}
$$

efektivitas guru dalam pembelajaran

$$
\begin{aligned}
& \mathrm{a}=\text { Konstanta } \\
& \mathrm{b}=\text { Koefisien regresi }
\end{aligned}
$$

\section{Koefisien Korelasi}

Analisis koefisien korelasi membahas derajat yaitu untuk menunjukkan kuat atau lemah serta arah hubungan antara variabel independent dan variabel dependent. Sedangakan ukuran yang digunakan untuk mengetahui seberapa besar derajat hubungan atau seberapa kuat hubungan yang terjadi antara variabel-variabel tersebut dinamakan pearson product moment, dengan rumus sebagai berikut:

$$
r_{\mathrm{y}}=\frac{n \sum x_{i} y_{i}-\left(\sum x_{i}\right)\left(\sum y_{i}\right)}{\sqrt{\left\{n \sum x_{i}^{2}-\left(\sum x_{i}\right)^{2}\right\}\left\{n \sum y_{i}^{2}-\left(\sum y_{i}\right)^{2}\right\}}}
$$

Pada hakekatnya, nilai $\mathrm{R}$ atau $\mathrm{r}$ dapat bervariasi dari -1 hingga +1 , atau secara matematis dapat ditulis menjadi $-1 \leq \mathrm{r} \leq+1$

a. Bilar $=0$ atau mendekati 0 , maka hubungan antara kedua variabel sangat lemah atau tidak terdapat hubungan sama sekali. b. Bila $\mathrm{r}=+1$ atau mendekati +1 , maka korelasi antara dua variabel dikatakan positif dan sangat kuat sekali.

c. Bila $\mathrm{r}=-1$ atau mendekati -1 , maka korelasinya sangat kuat dan negatif.

Tanda positif (+) dan negatif (-) pada koefisien memiliki arti yang khas. Bila $r$ positif, maka korelasi antara dua variabel bersifat searah. Dengan kata lain, kenaikan/ penurunan nilai-nilai variabel independent terjadi bersama-sama dengan kenaikan/ penurunan nilai-nilai variabel dependent. Sebaliknya, bila r negatif kenaikan nilai-nilai variabel independent terjadi bersama-sama dengan penurunan nilai variabel dependent atau sebaliknya.

Untuk dapat menginterpretasikan besar kecilnya koefisien korelasi antara variabel independent dengan variabel dependent, penulis menyajikan keeratan hubungan tersebut dalam bentuk tabel berikut ini.

\begin{tabular}{cc}
\hline Interval Koefisien & Tingkat Hubungan \\
\hline $0,00-0,199$ & Sangat rendah \\
\hline $0,20-0,399$ & Rendah \\
\hline $0,40-0,599$ & Cukup \\
\hline $0,60-0,799$ & Kuat \\
\hline $0,80-1,000$ & Sangat Kuat \\
\hline Sumber: Riduwan $(2009 ; 228)$
\end{tabular}

\section{Koefisien Determinasi}

Analisis koefisien determinasi yaitu analisis yang digunakan untuk mengetahui besarnya pengaruh variabel independent $(\mathrm{X})$ terhadap variabel dependent (Y). Besarnya koefisien determinasi adalah kuadrat dari koefisien korelasi $\left(\mathrm{R}^{2}\right)$. Nilai $\left(\mathrm{R}^{2}\right)$ mempunyai interval antara 0 sampai $1\left(0 \leq R^{2} \leq 1\right)$. Semakin besar $\mathrm{R}^{2}$ (mendekati 1), semakin baik hasil untuk model regresi tersebut dan semakin mendekati 0 , maka variable independent secara keseluruhan tidak dapat menjelaskan variable dependen. Rumus koefisien determinasi adalah:

$$
\mathrm{Kd}=\mathrm{R}^{2} \times 100 \%
$$




\section{Rancangan Pengujian Hipotesis}

Untuk menguji variabel bebas terhadap variabel tidak bebas, digunakan pengujian koefisien regresi secara (uji t). Nilai $t_{\text {hitung }}$ tersebut akan akan dibandingkan dengan nilai $t_{\text {tabel }}$ yang dipeorleh dari tabel $t$ dengan memakai tingkat risiko tertentu. Nilai $t_{\text {hitung }}$ dengan rumus:

$\mathrm{t}_{\text {hitung }}=\frac{b}{s b i}$

Dimana:

$\mathrm{bi}=$ Koefisien regresi masing-masing variabel sbi $=$ Standar error masing-masing variabel Kriteria uji yang dipakai adalah sebagai berikut:

- Ho diterima bila $=-\mathrm{t}_{\text {tabel }} \leq \mathrm{t}_{\text {hitung }} \leq \mathrm{t}_{\text {tabel }}$

- Ho ditolak bila $=\mathrm{t}_{\text {hitung }}>\mathrm{t}_{\text {tabel }}$ atau $-\mathrm{t}_{\text {hitung }}<$ $-t_{\text {tabel }}$

Bila terjadi penerimaan Ho, maka disimpulkan suatu pengaruh adalah tidak signifikan, sedangkan bila Ho ditolak artinya suatu pengaruh adalah signifikan. Tingkat signifikansi yang digunakan dalam penelitian ini adalah 0,05 atau 5\% karena dinilai cukup ketat untuk memiliki hubungan antara variabel-variabel yang diuji/menunjukkan bahwa korelasi antara kedua variabel cukup nyata, disamping itu tingkat signifikansi ini sudah umum digunakan dalam penelitian ilmu sosial.

\section{HASIL PEMBAHASAN}

\section{Kepemimpinan Efektivitas Guru dalam Pembelajaran di Kelas XI MA Assalam Baleendah}

Kepemimpinan guru pada dasarnya merupakan suatu proses untuk mempengaruhi orang lain yang didalamnya berisi serangkaian tindakan atau perilaku tertentu terhadap invididu yang dipengaruhinya. Kepemimpinan guru tidak hanya sebatas pada peran guru dalam konteks kelas pada saat berinteraksi dengan siswanya tetapi menjangkau pula peran guru dalam berinteraksi dengan kepala sekolah dan rekan sejawat, dengan tetap mengacu pada tujuan akhir yang sama yaitu terjadinya peningkatan proses dan hasil pembelajaran siswa.

\section{Kreativitas Siswa Kelas XI di MA Assalam Baleendah}

Kreativitas merupakan kemampuan seseorang menciptakan hal-hal yang baru, menghasilkan gagasan, menyelesaikan suatu masalah yang sebelumnya belum terpecahkan. Dalam konteks ini kreativitas akan mampu menghasilkan pribadi yang kreatif. Siswa dituntut untuk berpikir kreativ dalam proses pembelajaran di kelas. Guru dapat menumbuhkan sikap kreatif pada siswanya, dengan memberikan kesempatan pada siswa untuk dapat beraktifitas melalui kegiatan-kegiatan pembelajaran yang sifatnya bermain yang memungkinkan munculnya ide-ide kreatif siswa.

\section{Hubungan Kepemimpinan Efektivitas Guru dalam Pembelajaran dengan Kreativitas Siswa Kelas XI di MA Assalam Baleendah \\ a. Pengujian Validitas dan Reliabilitas Instrumen}

Hasil uji validitas untuk masing-masing variabel dijelaskan dalam bentuk tabel dibawah ini, perhitungan uji validitas dalam penelitian dibantu dengan menggunakan alat statistik yang ada dalam program SPSS 20.0 For Windows. Dan hasil perhitungan disajikan dalam lampiran.

Berdasarkan hasil uji validitas pada tabel tersebut diatas yaitu variabel $\mathrm{X}$ (Kepemimpinan efektivitas guru dalam pembelajaran) bahwa semua item lebih dari nilai kritis yaitu 0,3 , jadi dapat disimpulkan bahwa seluruh pertanyaan yaitu sebanyak 18 item adalah valid.

Berdasarkan hasil uji validitas pada tabel tersebut diatas yaitu variabel Y (Kreativitas siswa) bahwa semua item lebih dari nilai kritis yaitu 0,3 , jadi dapat disimpulkan bahwa seluruh pertanyaan yaitu sebanyak 17 item 
adalah valid.

Uji reliabilitas instrumen digunakan untuk menunjukan sampai sejauhmana suatu hasil pengukuran relatif konsisten apabila pengukuran dilakukan dua kali atau lebih. Dalam uji reliabilitas yang dilakukan dalam penelitian ini penulis menggunakan alat Bantu statistik yang ada dalam program SPSS 20.0 For Window yaitu dengan menggunakan rumus Cronbach's alpha. Diperoleh hasil pengujian variable $X$ sebagai berikut : Tabel

Hasil Uji Reliabilitas Variabel X

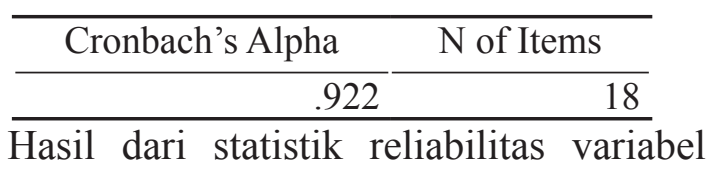

$\mathrm{X}$ diperoleh cronbach's Alpha lebih besar dari 0,6 yaitu $0,922>0,6$ yang menyatakan bahwa instrument tersebut reliabel.

Tabel

Hasil Uji Reliabilitas Variabel Y

\begin{tabular}{rr}
\hline Cronbach's Alpha & N of Items \\
\hline .922 & 17 \\
\hline
\end{tabular}

Hasil dari statistik reliabilitas variabel Y diperoleh cronbach's Alpha lebih besar dari 0,6 yaitu $0,922>0,6$ yang menyatakan bahwa instrument tersebut reliabel.

\section{b. Uji Normalitas}

Uji normalitas bertujuan untuk menguji apakah dalam model regresi, variabel pengganggu/residual memiliki distribusi normal.

Tabel

Uji Normalitas

\begin{tabular}{|c|c|c|}
\hline & & $\begin{array}{l}\text { Unstandardiz ed } \\
\text { Residual }\end{array}$ \\
\hline $\mathrm{N}$ & & 28 \\
\hline Normal Parameters a.b & Mean & $\begin{array}{r}\text { OE-7 } \\
\end{array}$ \\
\hline Most Estreme Differences & $\begin{array}{l}\text { Absolute } \\
\text { Positive } \\
\text { Negative }\end{array}$ & $\begin{array}{r}.124 \\
.094 \\
-.124 \\
\end{array}$ \\
\hline Kolmogorov-Smirnov Z & & .657 \\
\hline Aymp. Sig. (2-tailed) & & .781 \\
\hline
\end{tabular}

Berdasarkan tabel di atas, karena angka Sig. $(0,781)$ lebih besar dari 0,05 data tersebut berdistribusi normal, maka model regresi memenuhi asumsi normalitas.

\section{c. Analisis Regresi Sederhana}

Berdasarkan hasil pengolahan analisis regresi dengan satu variabel bebas (kepemimpinan efektivitas guru dalam pembelajaran) dan variabel terikat (Kreativitas siswa) maka Tabel diperoleh hasil analisis sebagai berikut:

\begin{tabular}{|c|c|c|c|c|c|c|}
\hline \multirow[b]{2}{*}{ Model } & & \multicolumn{2}{|c|}{$\begin{array}{l}\text { Unstandardized } \\
\text { Coefficients }\end{array}$} & $\begin{array}{l}\text { Standardized } \\
\text { Coefficients }\end{array}$ & \multirow[b]{2}{*}{$\mathrm{t}$} & \multirow[b]{2}{*}{ Sig. } \\
\hline & & $\bar{B}$ & Stad. Error & Beta & & \\
\hline 1 & (Constant) & 24.247 & 8.786 & & 2.760 & .010 \\
\hline & $\mathrm{x}$ & .592 & .144 & .627 & 4.104 & .000 \\
\hline
\end{tabular}

a. Dependent Variable: y

Hasil analisis regresi menunjukkan bahwa besarnya nilai konstanta yang dihasilkan adalah 24,247 dan koefisien regresi untuk kreativitas siswa sebesar 0,592. Persamaan

regresi : $\mathrm{Y}=24,247+0,592 \mathrm{X}$

Adapun yang dimaksud (interprestasi) dari persamaan regresi yang dihasilkan adalah: 
$\mathrm{a}=24,247$ : merupakan konstanta (a) yang menunjukkan apabila variabel kepemimpinan efektivitas guru dalam pembelajaran konstan, maka besarnya kreativitas siswasebesar 24,247 satuan.

$\mathrm{b}=0,592$ : merupakan nilai koefisien regresi variabel $\mathrm{X}$ (kepemimpinan efektivitas guru dalam pembelajaran) yang menunjukkan bahwa apabila kepemimpinan efektivitas guru dalam pembelajaran mengalami peningkatan sebesar 1 satuan, maka kreativitas siswa akan meningkat sebesar 0,592 satuan.

\section{d. Koefisien Korelasi}

Analisis koefisien korelasi digunakan untuk mengetahui tingkat hubungan dua variabel, yaitu variable bebas dan varibel tidak bebas.

Tabel

Koefisien Korelasi

Model Summary

\begin{tabular}{crrrr}
\hline Model & $\mathrm{R}$ & R Square & Adjusted R Square & $\begin{array}{c}\text { Std. Error of } \\
\text { Estimate }\end{array}$ \\
\hline 1 & .627 & .393 & .370 & 13.51462 \\
\hline
\end{tabular}

Berdasarkan tabel di atas, besarnya korelasi antara Kreativitas siswa dengan kepemimpinan efektivitas guru dalam pembelajaran sebesar 0,627. Hal ini menandakan adanya hubungan yang kuat antara kepemimpinan efektivitas guru dalam pembelajaran dengan kreativitas siswa.

\section{e. Koefisien Determinasi}

Berdasarkan tabel koefisien korelasi di atas, besar pengaruh kepemimpinan efektivitas guru dalam pembelajaran terhadap Kreativitas siswa sebesar 39,3\% dan sisanya $60,7 \%$ yang dipengaruhi oleh faktor-faktor

Tabel

Pengujian Hipoetsis

Coefficients

\begin{tabular}{|c|c|c|c|c|c|c|}
\hline \multirow[b]{2}{*}{ Model } & & $\begin{array}{l}\text { Unstandardi } \\
\text { Coefficients }\end{array}$ & & $\begin{array}{l}\text { Standardized } \\
\text { Coefficients }\end{array}$ & \multirow[b]{2}{*}{$\mathrm{t}$} & \multirow[b]{2}{*}{ Sig. } \\
\hline & & $\mathrm{B}$ & Stad. Error & Beta & & \\
\hline 1 & (Constant) & 24.247 & 8.786 & & 2.760 & .010 \\
\hline & $\mathrm{x}$ & .592 & .144 & .627 & 4.104 & .000 \\
\hline
\end{tabular}

a. Dependent Variable: $y$

Berdasarkan tabel diperoleh nilai signifikansi sebesar 0,000 . Karena nilai signifikansi lebih kecil dari $\alpha=5 \%$ yaitu $0,000<0,05$, maka Ho ditolak. Artinya terdapat hubungan antara kepemimpinan efektivitas guru dalam pembelajaran dengan kreativitas siswa Kelas XI di MA Assalam Baleendah.

Kaitan kreativitas dengan proses di luar kepemimpinan efektivitas guru dalam pembelajaran yang tidak diteliti oleh peneliti.

\section{f. Uji Hipotesis}

Hipotesis penelitian secara parsial adalah:

Ha $: \rho=0$ Tidak terdapat hubungan antara kepemimpinan efektivitas guru dalam pembelajaran dengan kreativitas siswa Kelas XI di MA Assalam Baleendah

Ho : $\rho \neq 0$ Terdapat hubungan antara kepemimpinan efektivitas guru dalam pembelajaran dengan kreativitas siswa Kelas XI di MA Assalam Baleendah 
yang diberikan di sekolah, membekali siswa dengan kreativitas, berarti member mereka peralatan yang diperlukan untuk hidup dan berkembang yang tidak hanya pada masa kini, tetapi juga untuk masa yang akan datang.

Dalam proses pembelajaran di kelompok bermain, kreativitas anak dirangsang dan dieksplorasi melalui kegiatan bermain sambil belajar sebab bermain merupakan sifat alami anak. Guru merupakan komponen terpenting dalam kesuksesan pembelajaran. Daresh dan Playco (1995) mendefinikan kepemimpinan pembelajaran sebagai upaya memimpin para guru agar mengajar lebih baik, yang pada gilirannya dapat memperbaiki prestasi belajar siswanya. Kepemimpinan pembelajaran adalah kepemimpinan yang memfokuskan/ menekankan pada pembelajaran yang komponen-komponennya meliputi kurikulum, proses belajar mengajar, asesmen (penilaian hasil belajar), penilaian serta pengembangan guru, layanan yang optimal dalam pembelajaran, dan pembangunan komunitas belajar di sekolah.

Dalam proses pembelajaran, pendidik bertanggungjawab dalam membimbing dan mengarahkan anak agar menjadi kreatif Kreativitas merupakan ekspresi dari keunikan individu dalam berinteraksi dengan lingkungannya. Ungkapan kreatif inilah yang mencerminkan orisinalitas dari individu, dari ungkapan pribadi inilah diharapkan timbul ide-ide baru dan produk-produk yang inovatif. Sebagai seorang guru/pendidik hendaknya dapat menghargai dan membantu menemukan dan mengembangkan bakat tersebut. Dalam mewujudkan dan mengembangkan bakat kreatif anak diperlukan dorongan (motivasi), baik dari dalam diri (motivasi internal) maupun dari lingkungan sekitar yang berupa suasana kondusif, apresiasi, pujian dan lain sebagainya (motivasi eksternal). Untuk itu pengembangan kreativitas tidak dapat dilakukan dengan kegiatan belajar yang bersifat ekspositori melainkan dengan kegiatan belajar discovery/inquiry. Dengan demikian, pendidik hendaknya menciptakan suasana belajar yang lebih banyak memberikan kesempatan untuk berfikir kreatif, mengembangkan gagasan atau konsep-konsep siswa sendiri dan melakukan berbagai percobaan. Keadaan demikian inilah, menuntut pula sikap yang lebih demokratis, terbuka, bersahabat dan percaya terhadap siswa.

Pentingnya berpikir kreatif bagi siswa yaitu lebih melibatkan siswa sebagai pemikir, menigkatkan perilaku kreatif, menggerakan potensi kreativitas siswa dalam mengumpulkan suatu ide dan siswa terlibat secara aktif dalam proses pembelajaran. Tugas utama guru dalam mengelola pembelajaran untuk mengasah keterampilan siswa berpikir kreatif mencakup merancang perencanaan pembelajaran melalui perumusan Rencana Pelaksanaan Pembelajaran (RPP), menerapkan rencana pembelajaran dalam kegiatan belajar siswa, menilai proses dan hasil belajar siswa, dan mengevaluasi pembelajaran.

\section{SIMPULAN}

Berdasarkan penelitian yang penulis lakukan melalui analisis data statistik dari kuesioner yang disebarkan dan observasi, maka dapat ditarik simpulan sebagai berikut:

1. Kepemimpinan efektivitas guru dalam pembelajaran di Kelas XI MA Assalam Baleendah berdasarkan indikator memiliki akuntabilitas tinggi untuk memelopori perubahan organisaional sehingga bisa membuat perbedaan yang berarti, terbuka menerima ide inovatif untuk membangun komunikasi interpersonal yang positif, membangun kekuatan tanpa mengabaikan sisi kelemahan, berani menghadapi tantangan, proaktif menyambut peluang, belajar dari pengalaman, stabil memperbaiki kesalahan, mengembangkan dan memotivasi peningkatan kemampuan SDM, mengoptimalkan penguasaan kompetensi sebagai pemimpin profesional, dan memanfaatkan hallo 
effect untuk membangun networking sudah dilaksanakan dengan cukup baik

2. Kreativitas siswa Kelas XI di MA Assalam Baleendah berdasarkan indikator keterampilan berpikir lancar (fluency), keterampilan berpikir luwes (flexibility), keterampilan berpikir orisinil (originality), keterampilan merinci (elaboration), dan keterampilan menilai (evaluation) mendapat penilaian cukup baik.

3. Terdapat hubungan kepemimpinan efektivitas guru dalam pembelajaran dengan kreativitas siswa Kelas XI di MA Assalam Baleendah.

\section{DAFTAR RUJUKAN}

Aan Komariah dan Cepi Triatna. (2005). Visionary Leadership Menuju Sekolah. Efektif. Jakarta: Bumi Aksara

Achmad Sanusi. (2009). Kepemimpinan Sekarang dan Masa Depan dalam Membentuk Budaya Organisasi yang Efektif. Bandung: Prospect

Ahmad, Rohani. (2010). Pengelolaan Pembelajaran. Jakarta: PT Rineka Cipta

Alfian. (1983). Kreativitas dalam Perdebatan. Dian Rakyat, Jakarta

Andang Ismail. (2006). Education Games. Menjadi Cerdas dan Ceria dengan Permianan Edukatif. Yogyakarta : Pilar Media

Arikunto, Suharsimi. (2010). Prosedur Penelitian Suatu Pendekatan Praktik. Jakarta : Rineka Cipta

Creswell, John W. (2010). Research Design Pendekatan Kualitatif, Kuantitatif, dan. Mixed.Yogyakarta : Pustaka Pelajar.

Daresh, John C.,Playko, Marshal A. (1995). Supervision as a Proactive Process, Waveland press

Edy Sutrisno. (2011). Manajemen Sumber Daya Manusia. Jakarta: Kencana

Elizabeth B. Hurlock. (1978). Perkembangan Anak. Jakarta: Penerbit Erlangga

George R. Terry, (2003), Prinsip-prinsip Manajemen, PT. Bumi Aksara

Hadari Nawawi\& Martini Hadari (2004). Kepemimpinan yang Efektif. Yogyakarta: Gadjah Mada University Press.

Hersey dan Blanchard (2004). Management of Organizational Behavior : Utilizing. Human Resources, Prentice Hall, New Jersey

Ismail (2003). Media Pembelajaran (Model-model Pembelajaran). Proyek Peningkatan Mutu SLTP. Jakarta

Juliantine. (2009). Model-model pembelajaran Pendidikan Jasmani. FPOK. Bahan Ajar. Bandung. FPOK UPI

Kartini Kartono. (2005). Pemimpin dan Kepemimpinan. Jakarta: Rajawali Pers

Khabibah, Siti. (2006). Pengembangan Model Pembelajaran Matematika Dengan Soal Terbuka Untuk Meningkatkan Kreativitas Siswa Sekolah Dasar. Surabaya: UNS

Kisti, H. H dan Fardana N. A. (2012). Hubungan Antara Self Efficacy dengan Kreativitas Pada Siswa SMK. Jurnal Psikologi Klinis dan Kesehatan Mental. 1,(2),52-58

Masyuri dan Zainuddin. (2011). Metodologi Penelitian-Pendekatan Praktis dan Aplikatif. Bandung: PT Refika Aditama.

Miftah Thoha. (2010). Kepemimpinan dan Manajemen, Devisi Buku Perguruan Tinggi, PT. Raja Grafindo Persada, Jakarta

Mulyasa. E. (2009). Menjadi Guru Profesional Menciptakan Pembelajaran Kreatif dan Menyenangkan. Bandung: Remaja Rosdakarya.

Munandar, Utami. (2009). Pengembangan kreativitas Anak Berbakat. Jakarta : Rineka Cipta

Nasution (2003). Metode Research, Jakarta : PT. Bumi Aksara

Nazir (2012). Metode Penelitian, Jakarta : Ghalia Indonesia 
Ngalim Purwanto. (1991). Administrasi dan Supervisi Pendidikan, Bandung: PT. Remaja Rosdakarya

Riduwan (2012). Belajar Mudah Penelitian Untuk Guru, Karyawan, Peneliti Pemula. Bandung: Alfabeta

Rivai, Veitzal., (2003), Manajemen Sumber Daya Manusia untuk Perusahaan: Dari Teori ke Praktik. Jakarta: PT.Rajagrafindo Persada

Riyanto, Yatim. (2010). Paradigma Baru Pembelajaran, Jakarta: Kencana

Satiadarma, M. P. (2003). Mendidik Kecerdasan. Jakarta: Pustaka Populer Obor

Siagian, P. Sondang (2012). Sistem Informasi Manajemen. Jakarta: Bumi Aksara

Sopiah. (2008). Perilaku Organisasi, Andi, Yogyakarta

Sudarwan Danim. (2008). Pengantar Kependidikan. Bandung : Alfabeta

Sugiyono. (2012). Metode Penelitian Kuantitatif Kualitatif dan R\&B. Bandung: Alfabeta

Sukardi (2004). Metodologi Penelitian Pendidikan. Jakarta: PT Bumi Aksara

Tjutju Yuniarsih, \& Suwatno, (2008). Manajemen Sumber Daya Manusia Teori, Aplikasi dan Isu Penelitian. Bandung: CV. Alfabeta

Wahjosumidjo. (2002). Kepemimpinan Kepala Sekolah Tinjauan Teoritik dan Permasalahannya. Jakarta: Rajawali Pers

Wahyudi (2009). Kepemimpinan Kepala Sekolah dalam Organisasi Pembelajaran (Learning Organization). Bandung: Alfa beta 